\title{
Adenocarcinoma of the lung presenting with massive subcutaneous emphysema
}

\author{
Mashrafi Ahmed, Tahmina Begum
}

Texas Tech University, Amarillo, Texas, USA

\section{Correspondence to}

Dr Mashrafi Ahmed,

mashrafi.ahmed@ttuhsc.edu

Accepted 9 July 2015
CrossMark

To cite: Ahmed M, Begum T. BMJ Case Rep Published online: [please include Day Month Year] doi:10.1136/bcr-2015211649

\section{DESCRIPTION}

A 47-year-old woman presented to the emergency department (ED) with severe shortness of breath with a choking sensation for the past $4 \mathrm{~h}$. In the early morning, she had called her primary care physician with mild shortness of breath and was advised to take an albuterol inhaler for her chronic obstructive pulmonary disease (COPD). Despite following the general practitioner's advice, her condition worsened with development of facial and neck swelling. She did not have any history of bee sting or consumption or contact with any allergic substance. On arrival at the ED, she displayed significant swelling (figure 1A), prompting epinephrine administration for suspected angio-oedema; with no improvement. A careful examination revealed subcutaneous crepitations, reduced breath sound on the right side with hyperresonant percussion note. A CT scan of the head, neck and chest showed right-sided pneumothorax (figure 2, yellow arrow), pneumomediastinum and subcutaneous emphysema (figure 2, green arrow) involving the neck, and the face, up to the eyelids. No mass lesion was seen in the CT scan. Two chest tubes were immediately inserted. However, the right lung remained collapsed for the next 2 days. Bronchoscopy was performed, which showed an endobronchial obstructing mass. Endobronchial ablation of the tumour using a Nd:Yag laser allowed identification of a distal bronchopleural fistula. The fistula was successfully treated by placement of a one-way endobronchial valve. The biopsy obtained during the procedure revealed endobronchial adenocarcinoma. After resolution of the emphysema (figure 1B), the patient was referred to the oncologist for further management.

Spontaneous pneumothorax (SP) can be primary or secondary. The primary type occurs, without any apparent cause, in healthy individuals. The secondary type develops mostly due to malignancy, COPD, cystic fibrosis, pulmonary infection and diffuse lung disease. ${ }^{1}$ Only $2 \%$ of all SP may be due to malignant lung diseases; either primary or metastatic. ${ }^{1}$ The

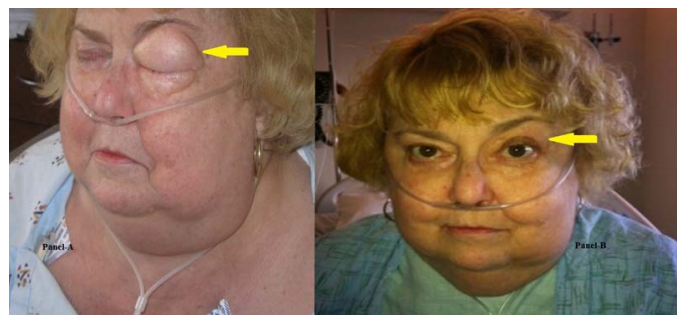

Figure 1 Subcutaneous emphysema extending up to the eyelids ( $A$, yellow arrow), and resolution of emphysema after chest tube and endobronchial valve placement ( $B$, yellow arrow).

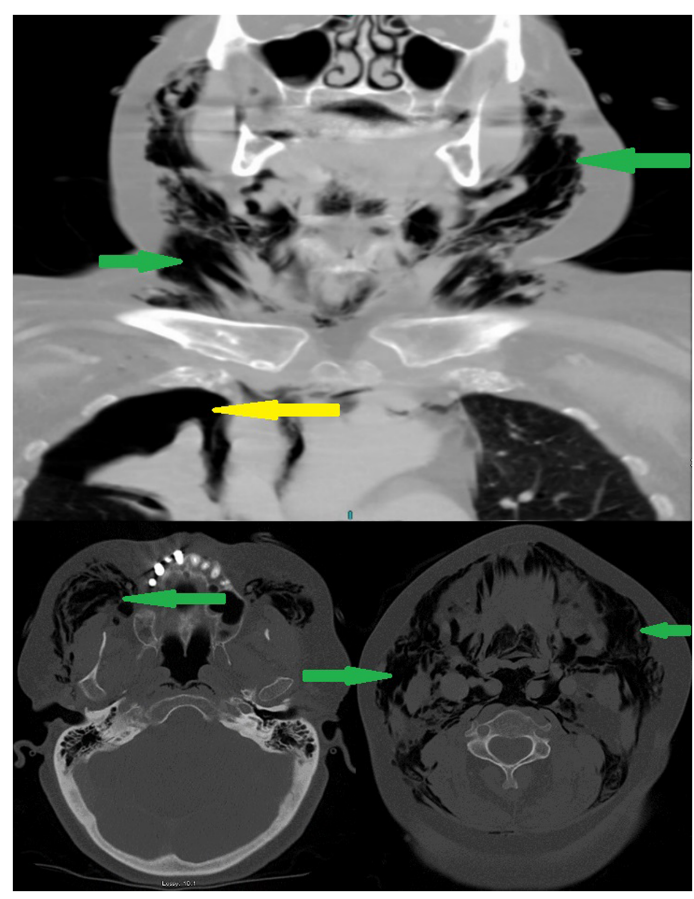

Figure 2 CT scan of the head, neck and chest showing right-sided pneumothorax (yellow arrow) and extensive subcutaneous emphysema (green arrow).

main cause of SP is the rupture of a necrotic tumour nodule or necrosis of subpleural metastases resulting in communication between the bronchus and pleural cavity, producing a bronchopleural fistula that results in pneumothorax. ${ }^{1}$ Subcutaneous emphysema associated with secondary SP due to lung cancer is exceedingly rare. A brief review of seven cases was published by Barquero-Romero and Redondo-Moralo. ${ }^{2}$ Overall prognosis is poor for this group of patients. Four out of seven patients died within 30 days of presentation. ${ }^{2}$

\section{Learning points}

- Primary lung cancer may present with spontaneous pneumothorax and subcutaneous emphysema.

- Previous chemotherapy and radiotherapy increase the risk of such presentation.

- Overall prognosis is very poor with more than $50 \%$ mortality reported within 30 days.

Competing interests None declared.

Patient consent Obtained.

Provenance and peer review Not commissioned; externally peer reviewed. 


\section{REFERENCES}

1 Vencevičius V, Cicenas $S$. Spontaneous pneumothorax as a first sign of pulmonary carcinoma. World J Surg Oncol 2009;7:57.
2 Barquero-Romero J, Redondo-Moralo MJ. Spontaneous pneumomediastinum and subcutaneous emphysema: an uncommon complication of lung cancer. Arch Bronconeumol 2009;45:309-10.

Copyright 2015 BMJ Publishing Group. All rights reserved. For permission to reuse any of this content visit http://group.bmj.com/group/rights-licensing/permissions.

BMJ Case Report Fellows may re-use this article for personal use and teaching without any further permission.

Become a Fellow of BMJ Case Reports today and you can:

- Submit as many cases as you like

- Enjoy fast sympathetic peer review and rapid publication of accepted articles

- Access all the published articles

- Re-use any of the published material for personal use and teaching without further permission

For information on Institutional Fellowships contact consortiasales@bmjgroup.com

Visit casereports.bmj.com for more articles like this and to become a Fellow 